\title{
Teaching English for Young Learners by Using Arduino
}

\author{
Rengganis Siwi Amumpuni ${ }^{1 *}$, Dian Ratnaningtyas Afifah ${ }^{1}$, Ihtiari $\mathrm{P}^{1}$
}

\author{
${ }^{1}$ Universitas PGRI Madiun \\ *Corresponding author. Email:rengganissiwi@unipma.ac.id
}

\begin{abstract}
The purpose of this research is to know the implementation of Arduino in teaching English for young learners, the advantages and disadvantages of Arduino in teaching English for young learners. Arduino is an open-source hardware prototyping platform that can be used to create programming based projects. It contains pictures, words and sound. This research uses a descriptive qualitative approach. Then for the sample is class B1 and the English teacher of that class. The total of the students are 20 students. Observation, interview and documentation are used as an instrument. Technique of analyzing data is using three techniques; they are reducing data, displaying data, and conclusion/verification. The result of the research show that the implementation of Arduino in teaching English for young learners has three activities. Pre activities, whilst activities and post activities. Greeting, praying, checking students' attendance and explaining the purpose of the meeting are all of the activities in the beginning or pre activities. The teacher demonstrates the implementation of Arduino in the classroom in the whilst activities. Lastly, reviewing and making resume of the material are posted activities. Advantages of the implementation of Arduino can help the students to learn English easily, motivate to learn English, train the students' concentration, and make the students enjoy in the class. There are some disadvantages of this research; first, it takes a long time because the teacher needs more time to prepare and turn the picture. Second, the class become noisy.
\end{abstract}

Keywords: Arduino, Teaching English, Young Learners

\section{INTRODUCTION}

English is an international language that must be learned by the students in globalization era. English is spoken in the most international even and it is used as the medium of the information on science, technology, and culture [1]. There are four skills that must be taught by teachers to students in English. They are listening, speaking, reading and writing. There are some language skill components that must be learn by the students in English. Some components of language are grammar, vocabulary, pronunciation, and spelling [2]. In teaching English, ability to speak is the most essential skill because it is basic for communication with others. Selecting the suitable materials and create a good atmosphere for learners help to determine the success of teaching [3].

Teaching English in Indonesia begins since elementary students to university students, but its implementation in fact shows the different result. This is seen from some research about the application of Teaching English for Young Learners (TEYL) was still far from curriculum expectation. Teaching English for young learners, especially for kindergarten students is part of hidden curriculum. The implementation of English only as a complement in teaching learning process in Indonesia. In TEYL, it's different from adults. There are several requirements that needed to create effective teaching English for young learners. Some children characteristics are concerning with their short attention span. The attention span means the amount of time which the children remains on the task without any destruction [4].

It can be seen during the lesson in teaching learning process. Children have short attention span than adults, they only have attention span less than 20 minutes [4]. Understanding the characteristics of young learners is important requirements for the teacher in creating appropriate media. Media is all material that used by teachers in teaching the students and it supports students in reaching the objective. There are alot of media that can be used by teachers in classroom. One of instructional media is Computer -based presentation technology. Hardware and software are two vital components in the instructional media [3].

There is some research about the using of Arduino. Arduino exchange computer programming course in science and engineering [5]. Using Arduino to teach Digital signal processing [6] and low-cost and simple Arduino for robotics kit [7] Arduino is one of media in Teaching Learning Process. Arduino is a hardware prototyping platform that can be used to create programming based projects. Arduino is used widely in learning, as an example for learning in computational physic. Besides that, in the learning of robotic technology, making simple technologybased modules, as well as several laboratory projects are 
also made using the Arduino uno platform [7,8,9]. Arduino is usually using for creating programs that used to make English language learning media for young children. Programs run in the media are designed for designs in the form of images and writing. In this case the basic algorithm for running text is modified so that an algorithm that can represent an image can be made. There are a lot of researcher that using Arduino for their research. In this case, the objective of the research is to know implementation of Arduino in TEYL, the advantages and disadvantages of implementation of Arduino in TEYL.

\section{METHOD}

This research is conducted at TKIT Nur Mujahidin Madiun. This research is qualitative research. It is about contextual conditions in the sosial institutional and the environment within people's lives and take place [10]. By using qualitative approach, it can describe about the social condition in the classroom during the implementaion of Arduino in teaching English. Social situation, participant, and document are as sources of data. There are three component in social situation; place, actor and activities [11]. The researcher observed activity, place and actor in implementation of Arduino in teaching English. The participant is taken from teacher and students of TKIT Nur Mujahidin Madiun. The students here are the member of class B that consists of 20 students. Meanwhile, the document used rpp and picture. The instrument that used are observation interview and documentations. They are used to collect the data. Interviews provide some information that cannot be obtained through observation. Interview is one of the basic methods for obtaining qualitative data. By doing interview, we can get the data about opinion, beliefs and situations from the people in theirs words [12]. Documents include video recordings, photographs, or other items that provide insight related to the context or participants. Triangulation is used to know the validity of the data. There are three different sources of information in Triangulation that will be help to give an idea in confirming and improving the precious of research finding [13]. Data reduction, data display, conclusion and verification are used to analyze the data [14]. Selecting, focusing, simplifying, abstracting and transforming the data that written in a note or transcriptions are all activities in data reduction. The researcher uses data from activities during class to know the teaching English by using Arduino and also uses the data from the interview with teachers and some students to know advantages and disadvantages by Using Arduino. Next procedure is data display, the researcher display the data in order to give clear description of Arduino in teaching process, the data from observation is the process in teaching English by using Arduino, the data from documentation is the condition of the classes, data from interview is about the process in teaching English by using Arduino, the advantages and disadvantages of the implementation Arduino in the learning process. After data condensation and displaying data, drawing conclusion and verification is the last step. After the process of collecting data are ended conclucion will appear.

\section{RESULT AND DISCUSSION}

\subsection{Result}

Based on the observation, the data can be collected by observing the teaching activities during teaching English by using Arduino are: The Implementation of Arduino in teaching English for young learners consist of three activities. Pre,whilst and post activities. In the preactivities, first the teacher greets the students in thr beginning of the lesson and pray together. Second, the teacher checks the students' presence. Third, teacher explains the purpose of the material. The whilst-activities, there are some steps in this activity. First, the teacher explains about part of body to the students. Then, the teacher turns on the Arduino. Second, the student immitate to tell the part of body based on the arduino. Third, the teacher asks the student some question related with part of body based on the arduino. In the post-activities, the teacher and students are reviewing and making summaries of the material. Finally, teacher closes the class. Interview is divided into two sessions. The first, the researcher interviews the teacher, second, researcher interviews students. The results of interviews are as follows: advantages and disadvantages of Arduino in teaching English for young learners. Advantages of using Arduino in teaching young learners are : It can help the students to learn English easily because the media is interesting for them to learn, motivate to learn English, help the students' concentration, and make the students happy in the class. The disadvantages of using Arduino in TEYL are : first, it needs a long time because the teacher needs more time to prepare and turn the picture. Second, the class become noisy. Based on the documentation, teaching English by using Arduino taken by researcher from RPP and photograph.

\subsection{Discussion}

Based on the result above, the researcher showed the discussions. They are described as follows:

1. Implementation of Arduino in TEYL.

a.The pre-activities in implementation of Arduino in teaching English for young learners are relevant with checklist of observation and lesson plan. There are three activities in this part. Greeting, checking the attendance and telling the purpose of the material.

b. Whilst-activities of implementation of Arduino in teaching English for young learners are relevant with checklist of observation, lesson plan. There are three activities in this part. Explaining parts of body, turning on the Arduino and asking some question related with the material.

c. The post-activities of implementation of Arduino in teaching English for young learners are relevant with lesson 
plan that used and checklist of observation. Reviewing material, making summaries and closing the material.

2. The Advantages of implementation of Arduino in TEYL.

a. Students are interested during the lesson, so they can know and understand of the lesson easily.

Students fell not confused to the lesson in the class. Arduino is interesting media for the students because it contains of some pictures. It same with the interview of the teacher who said that they happy follow the lesson because media is interesting and there are a lot of interactive picture. Moreover, based on the interview of the students, students said that they love and enjoy in learning English because the picture is good. It means that Arduino helps them to learn English easily.

b. Arduino motivates the student to learn English.

By using Arduino, the students motivate to learn English because the media is interesting. It based on the students' interview who said that they are happy in learning English. It means that arduino motivates the students to learn English.

c. Arduino trains the students' concentration.

By using arduino, the students feel better focus in learning because they have to pay attention of each picture which given by the teacher. Therefore, it can train the students' concentration. It based on the interview of the teachers who said, that by using arduino the students can concentrate better than using picture in learning English. It means that arduino help the students more concentrate read the text. Moreover, based on the interview of the students who said that the picture in arduino help them to remember well. It means that arduino can train the students' concentration so they can think more quickly.

d. Arduino makes the students enjoy in learning English.

By using arduino, the students can enjoy during class because the media contains a lot of interesting picture. It based on the students' interview who said that the class is good because the media have alot of interested interactive picture. It means that arduino gives a variation way to teach English for the young learners so they feel enjoy during teaching learning process.

3. The disadvantages of implementation of Arduino in teaching English for young learners are as follows:

a. It takes a long time because the teacher prepares the media and the turn the picture.

The media doesn't have remote and stil using conventional operation technique. Arduino need more times to apply because the media doesn't have remote and still using conventional operation technique. It based on the teacher's interview who said that the using of arduino need a lot of time because the media still using manual technique in moving the picture. It means that the media needs more time to apply in the classroom.

b. The class become noisy because the students talk with their friend to discuss the picture.

The implementation of Arduino make the class become noisy because the student busy with them self and talk with their friend discuss the picture. It based on the teacher's interview who said that the student interested with the picture so sometimes they talk with their friend. It means that the class become noisy.

\section{CONCLUSION}

In conclusion, the implementation of Arduino in TEYL in TKIT Nur Mujahidin has three steps included pre-activity, whilst-activity, and post-activity. Implementation is suitable with observation's checklist and lesson plan. There are some advantages of teaching English for young learners by using arduino in TKIT Nur Mujahidin. First, it can help the students to learn English easily, motivate to learn English, help the students' concentration, and make students happy in the class. Meanwhile, disadvantages are; first, it needs a long time because the teacher needs time to prepare and turn the picture. Second, the class become noisy.

\section{REFERENCES}

[1] Brown, H. Douglas. 2000. Teaching by Principles. San Francisco: Longman

[2] Nunan, David. 2003. Practical English Language Teaching. New York: McGraw-Hill

[3] Harmer, Jeremy. 2007. The Practice of English Language Teaching. New York: Longman

[4] Musthafa, Bacharudin. (2010). Teaching English to Young Learners in Indonesia: Essential Requirements. Educationist Journal. Vol 4, (2), 120 -135.

[5] Rubio Miguel A, Carolina Manoso Hierro Carolina Manoso, Pablo Angel Perez de Madrid y. 2013.Using

Arduino to enhance computer programming courses in science and engineering. Proceedings of EDULEARN13 Conference. Barcelona. Spain

[6] Hochgraf Clark 2013.Arduino to Teach Digital Signal Process. ASEE Northeast Section Conference. Norwich University

[7] Luiz A. Junior et al. 2013. A Low-Cost and Simple Arduino-Based Educational Robotics Kit. Journal of Selected Areas in Robotics and Control (JSRC), December Edition, 2013 Volume 3, Issue 12.

[8] Pierre E Hertzog1 and Arthur J Swart. 2016. Arduino Enabling engineering students to obtain academic success in a design based module. IEEE Global Engineering Education Conference (EDUCON) Proceedings.

[9] Petre Lucian Ogrutan. 2017. Increasing Students' Interest by Encouraging them to Create Original Lab Projects. TEM Journal. Volume 6, Issue 4. 
[10] Yin, Robert K .2011. Qualitative Research from Start to Finish.United States of America: Guilford Press.

[11] Sugiyono. 2013. Metode Penelitian Kombinasi. Bandung: Alfabeta

[12] Ary, et al. 2010.Introduction to Research in Education. Canada. Wardsworth.

[13] Ritchie, Jane and Ritchie, Lewis. 2003. Qualitative Research Practice. London: Sage Publication

[14] Miles, M.B. 1994. Qualitative Data Analysis. London: Sage Publications 